\title{
Ontogeny of the opioidergic regulation of LH and prolactin secretion in lactating sow I: failure of naloxone to antagonize suckling-induced changes in LH and prolactin secretion in early lactation, irrespective of pattern of administration
}

\author{
F. De Rensis*, J. R. Cosgrove and G. R. Foxcroft ${ }^{\dagger}$ \\ Department of Agricultural, Food and Nutritional Science, $310 \mathrm{C}$ Agriculture/Forestry Centre, \\ University of Alberta, Edmonton. Alberta, T6G 2P5, Canada
}

\begin{abstract}
The principal aim of this study was to investigate the ontogeny of an opioidergic mechanism mediating the suckling-induced inhibition of LH secretion during lactation in sows. In contrast to an increase in LH secretion in response to naloxone treatment on days 10 and 11 of lactation $(P<0.05)$, a single injection of $2 \mathrm{mg}$ naloxone $\mathrm{kg}^{-1}$ at $39,51,63$ or $75 \mathrm{~h}$ post partum had no effect. However, the last of four injections of $2 \mathrm{mg}$ naloxone $\mathrm{kg}^{-1}$ given at $12 \mathrm{~h}$ intervals to group IV sows did elicit a positive $\mathrm{LH}$ response $(P<0.05)$. Multiple injections of $1 \mathrm{mg}$ naloxone $\mathrm{kg}^{-1}$ at $3 \mathrm{~h}$ intervals over $30 \mathrm{~h}$ on day $10-11$ consistently increased $(P<0.05)$ mean plasma $\mathrm{LH}$ with no evidence of induced refractoriness to repeated use of the antagonist. Similarly, naloxone did not affect mean plasma prolactin in the immediate postpartum period, but either repeated naloxone treatments on day 10-11, or single naloxone injections on day 10 or 11 of lactation decreased plasma prolactin $(P<0.05)$. Therefore, the regulation of $\mathrm{LH}$ and prolactin secretion in lactating sows changes with time post partum. An opioid-dependent mechanism is an important component of the suckling-dependent regulation of LH and prolactin secretion in established lactation, but not during the first $72 \mathrm{~h}$ postpartum period.
\end{abstract}

\section{Introduction}

Lactational anoestrus in sows is characterized by a suppression of LH secretion and a lack of follicular development (for review, see Britt et al., 1985; Varley and Foxcroft, 1990; Foxcroft, 1992). There is a substantial body of evidence supporting a role for endogenous opioids in the suppression of GnRH and LH secretion during established lactation in pigs, sheep and cattle (for review, see Haynes et al., 1989; Barb et al., 1991; Britt et al., 1992; De Rensis and Foxcroft, 1992). During established lactation, the blockade of opiate receptors with naloxone results in a decrease in prolactin secretion in ewes (Gregg et al., 1986) and sows (Barb et al., 1986; Mattioli et al., 1986; Armstrong et al., 1989; De Rensis et al., 1993a). Although suckling-induced suppression of LH secretion has been observed in the immediate postpartum period in sows (De Rensis et al., 1993b; Sesti and Britt, 1994), in a previous study (De Rensis et al., 1993a) chronic naloxone treatment did not prevent this initial suckling-induced inhibition of LH secretion. These data provided provisional evidence that, in contrast to the situation in established lactation, opioidergic inhibition of LH secretion may not occur during the early postpartum period

\footnotetext{
*Present address: Istituto di Clinica Ostetrica Veterinaria, Via del Taglio 8, 43100, Parma, Italy.

${ }^{+}$Correspondence.

Received 10 April 1997
}

in sows. However, the precise ontogeny of opioid-dependent regulation of $\mathrm{LH}$ and prolactin secretion in our earlier study (De Rensis et al., 1993a) may have been obscured by the multiple injection regimen of antagonist treatment.

Therefore, the primary aim of the present experiment was to challenge sows with single injections of the opioid antagonist naloxone at different times after farrowing, to define precisely the time at which endogenous opioids first become active in the control of $\mathrm{LH}$ and prolactin during lactation. Second, multiple repeat naloxone injections from day 10 to day 11 of lactation, when opioidergic regulation of $\mathrm{LH}$ and prolactin secretion is known to occur, were used to investigate the possible development of refractoriness to opioid antagonist treatment.

\section{Materials and Methods}

\section{Animals and blood collection}

Twenty primiparous Camborough $\times$ Canabrid sows (Pig Improvement (Canada) Ltd, Acme Alberta) from the University of Alberta herd were used in a replicated study. Oestrus was synchronized in groups of second or third cycle gilts to facilitate batch farrowing of ten animals in May and June. Sows were housed in conventional farrowing crates with water 


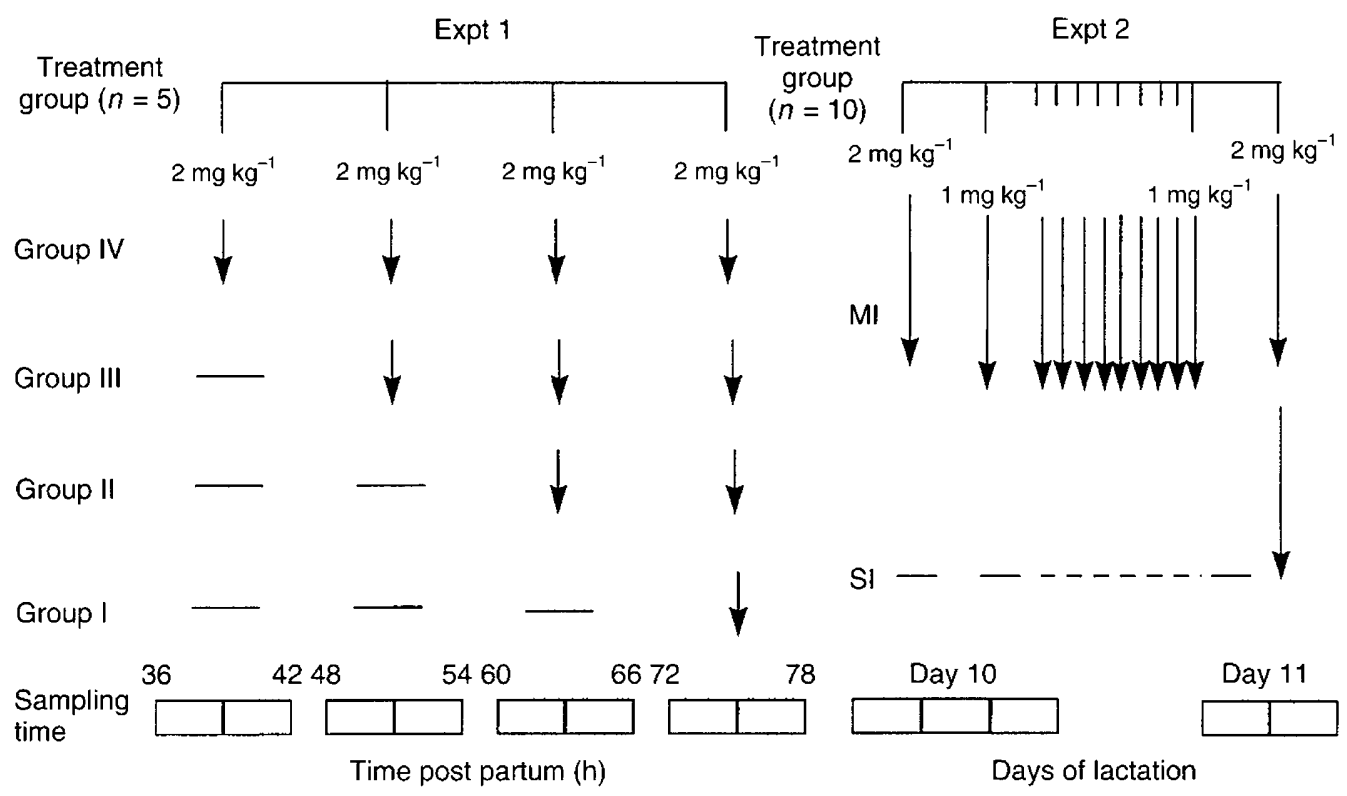

Fig. 1. Schematic diagram of the experimental design. Arrows indicate times of naloxone injections. Expt 1 comprised four subgroups (I-IV) of five sows each and Expt 2 comprised the same sows split between two groups (Single Injected (SI) and Multiple Injected (MI) sows) of ten sows each.

provided ad libitum and were fed a commercial sow lactation diet providing $15.4 \%$ crude protein and $13.4 \mathrm{MJ}$ of digestible energy $\mathrm{kg}^{-1}$ to appetite two times per day throughout lactation. These allowances met or exceeded recommended nutrient requirements and the experiment was conducted in accordance with Canadian Council of Animal Care guidelines. The average weight of the sows one day after farrowing was $198.0 \pm 8.3 \mathrm{~kg}$ and litter size was standardized immediately after farrowing to ten piglets per sow by cross fostering. Sows were provided surgically with indwelling jugular catheters via the cephalic vein under general anaesthesia $12-18 \mathrm{~h}$ after parturition according to established procedures (Cosgrove et al., 1993) to allow stress-free withdrawal of blood samples $(2.5 \mathrm{ml})$ at $15 \mathrm{~min}$ intervals during subsequent periods of sampling. The logistics of the experiment were facilitated by grouping sows that had completed farrowing within a $6 \mathrm{~h}$ period. The end of each $6 \mathrm{~h}$ period was then defined as $0 \mathrm{~h}$ post partum.

\section{Methods}

The experimental design (Fig. 1) comprised two parts. The ontogeny of opioid-dependent regulation of $\mathrm{LH}$ and prolactin secretion in early lactation was defined by sampling all animals in Expt 1 over $6 \mathrm{~h}$ periods from 36 to 42,48 to 54,60 to 66 and 72 to $78 \mathrm{~h}$ post partum. Five sows within each replicate were allocated to receive a single bolus i.v. injection of $2 \mathrm{mg}$ naloxone hydrochloride (Sigma, St Louis, MO) $\mathrm{kg}^{-1}$ in saline $3 \mathrm{~h}$ after the beginning of each period of sampling to define unequivocally the time at which opioid antagonism can first affect $\mathrm{LH}$ and prolactin secretion. Sows first treated at 39, 51 and $63 \mathrm{~h}$ post partum then received three, two or one further injections, respectively, of the same dose of naloxone during subsequent periods of sampling (Fig. 1). Therefore, within the subgroups, repeated injection regimens were used to elucidate further the ontogeny of opioidergic regulation of LH and prolactin. Given the known half-life of naloxone of approximately $75 \mathrm{~min}$ (Rockville, 1996), and experience from our previous study (De Rensis $e$ al., 1993a) that a dose of $2 \mathrm{mg}$ naloxone $\mathrm{kg}^{-1}$ will provide a robust and immediate LH and prolactin response, this treatment regimen was designed to provide additional data on the ontogeny of opioidergic regulation while avoiding carry-over effects of previous antagonist treatment. Responses to naloxone treatment in the immediate postpartum period were compared with responses to similar single bolus injections of naloxone first given on either day 10 (MI sows) or day 11 (SI sows) of lactation (see Expt 2 below).

In Expt 2, all sows were sampled over $9 \mathrm{~h}$ on day 10 and over $7 \mathrm{~h}$ on day 11 of lactation. The $9 \mathrm{~h}$ on day 10 allowed the response to the first two challenges with naloxone at the start of the multiple injection regimen to be characterized. The $7 \mathrm{~h}$ on day 11 allowed the last response to the $1 \mathrm{mg}$ naloxone $\mathrm{kg}^{-1}$ injection ( $1 \mathrm{~h}$ before and $3 \mathrm{~h}$ after injection) and then, in all sows, the response to the $2 \mathrm{mg}$ naloxone $\mathrm{kg}^{-1}$ dose given at the same time in lactation to be characterized. The possibility that the multiple naloxone injection regimen used in the previous study (De Rensis et al., 1993a) might result in decreased sensitivity to the opioid antagonist was evaluated by administering $2 \mathrm{mg}$ naloxone $\mathrm{kg}^{-1}$ i.v. $3 \mathrm{~h}$ after the start of sampling on day 10 , followed by ten further injections of $1 \mathrm{mg}$ naloxone $\mathrm{kg}^{-1}$ i.v. at $3 \mathrm{~h}$ intervals on days 10-1I of lactation and then a further challenge with $2 \mathrm{mg}$ naloxone $\mathrm{kg}^{-1}$ to ten sows (multiple injected sows: MI group), allocated in a stratified manner to account for Expt 1 treatments. Use of this naloxone treatment regimen assumes that the initial $2 \mathrm{mg}$ $\mathrm{kg}^{-1}$ dose establishes effective opioid antagonism and then the repeated $3 \mathrm{~h}$ doses of $1 \mathrm{mg} \mathrm{kg}^{-1}$ are adequate to maintain 

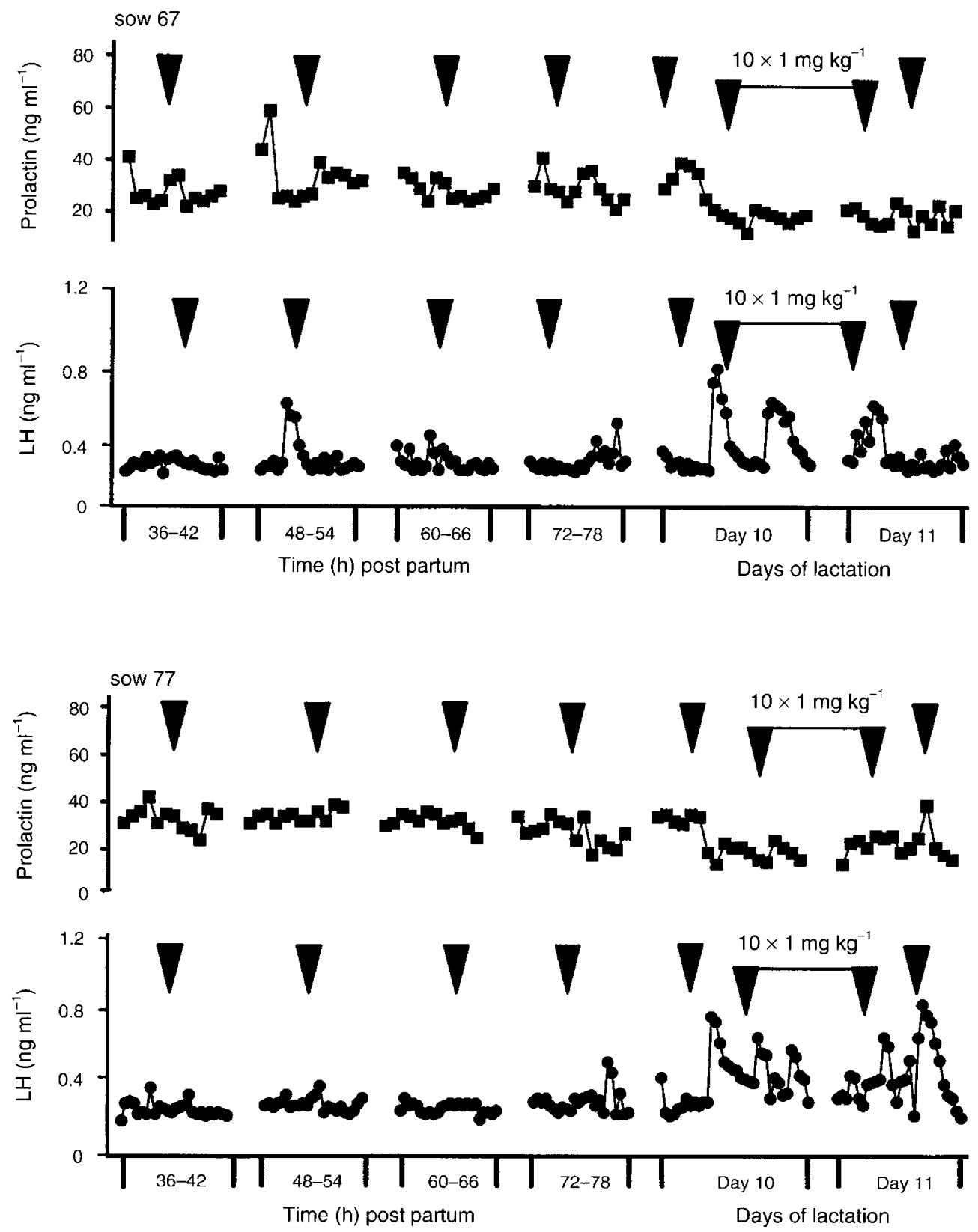

Fig. 2. Individual plasma prolactin and LH profiles in two group IV sows first treated with a bolus injection of $2 \mathrm{mg}$ naloxone $\mathrm{kg}^{-1}$ at $51,39,63$ or $75 \mathrm{~h}$ post partum in Expt 1 and allocated to multiple (ten) injections of naloxone ( $1 \mathrm{mg} \mathrm{kg}^{-1}$ each) before and after an additional challenge with the $2 \mathrm{mg}$ naloxone $\mathrm{kg}^{-1}$ on days 10 and 11 of lactation in Expt 2. Arrowheads indicate naloxone injections.

antagonist activity in a continuous manner. Ten sows (single injected sows: SI group) received saline vehicle only, during sampling on day 10 and the first $4 \mathrm{~h}$ on day 11 , and then received a single i.v. injection of $2 \mathrm{mg}$ naloxone $\mathrm{kg}^{-1} 4 \mathrm{~h}$ after the start of sampling on day 11 .

\section{Hormone assays}

Plasma LH was quantified in all samples using the double antibody radioimmunoassay described by De Rensis et al. (1993a). Inter- and intra-assay CVs were $12.7 \%$ and $4.1 \%$, respectively, and the sensitivity of the assay, defined as $90 \%$ of total binding, was $0.12 \mathrm{ng} \mathrm{ml}^{-1}$. Plasma prolactin concentrations were measured in samples drawn at 30 min intervals by the method described by Shaw and Foxcroft (1985) with minor modifications. Intra- and inter-assay $\mathrm{CVS}$ were 3.9 and $10.7 \%$, respectively, and the overall sensitivity of the assay, defined as $85 \%$ of total binding, was $1.9 \mathrm{ng} \mathrm{ml}^{-1}$.

\section{Statistical analysis}

Consideration of the plasma LH profiles in this study indicated that the adoption of computerized pulse analysis 
programs was inappropriate because in many cases discrete pulsatile secretion was not evident at times when plasma LH concentrations were clearly changing. Therefore, LH profiles were analysed using the sliding window technique described by Shaw and Foxcroft (1985) to provide minimum, mean and maximum characteristics of LH secretion and thus a complete and more appropriate method of analysis (Foxcroft et al., 1988). Preliminary analysis of the data derived from the sliding windows analysis indicated that treatment effects on minimum, maximum and mean LH characteristics were similar; therefore, only the data for mean LH and prolactin are presented.

Experiment 1. Periods of two $3 \mathrm{~h}$ means (before and after naloxone injection) were calculated for each $6 \mathrm{~h}$ window of sampling. Analysis of the effect of single injections of naloxone on mean plasma LH and prolactin concentrations during each window were then undertaken using the repeat measures PROC GLM procedure within the SAS statistical package (SAS, 1985). Sources of variation were groups, repeated measures of period and period by group. By design, in the case of treatment for group I, the main effect of postpartum period was absent from the model.

Experiment 2. Hormone concentrations during the $9 \mathrm{~h}$ frequent sampling period on day 10 were analysed as the means of three $3 \mathrm{~h}$ periods; the $7 \mathrm{~h}$ frequent sampling period on day 11 was analysed as the means for three periods of $1 \mathrm{~h}, 3 \mathrm{~h}$ and $3 \mathrm{~h}$, respectively. Because of unexpected differences in pretreatment LH concentrations between groups on day 10, treatment effects were analysed within group (SI group and MI group) using analysis of variance and fitting the effect of period within group. Where appropriate, comparison of period means within treatment group were made using the Student-Neuman-Keul procedure (Steel and Torrie, 1980).

\section{Results}

The individual patterns of $\mathrm{LH}$ and prolactin secretion in two sows of group IV are shown (Fig. 2).

\section{Plasma LH}

Experiment 1. Injection of $2 \mathrm{mg}$ naloxone $\mathrm{kg}^{-1}$ for the first time at 39, 51, 63 and $75 \mathrm{~h}$ post partum did not affect mean plasma LH concentrations (Fig. 3). The only response $(P<0.05)$ to naloxone was observed $72-78 \mathrm{~h}$ post partum in group IV sows treated three times previously with the antagonist.

Experiment 2. The first $2 \mathrm{mg}$ naloxone $\mathrm{kg}^{-1}$ injection in the MI group at day 10 and the single $2 \mathrm{mg}$ naloxone $\mathrm{kg}^{-1}$ injection in the SI group at day 11 increased $(P<0.05)$ mean $\mathrm{LH}$ concentrations. Repeated naloxone injections at $3 \mathrm{~h}$ intervals during day 10-11 of lactation in MI sows maintained increased $(P<0.05$ ) plasma LH compared with the pretreatment period (Fig. 4). Furthermore, the response to the $2 \mathrm{mg}$ naloxone $\mathrm{kg}^{-1}$ injection on day 11 in the MI sows was not different $(P>0.05)$ from the response to the first injection of $2 \mathrm{mg}$ naloxone $\mathrm{kg}^{-1}$ on day 10 in the same animals.

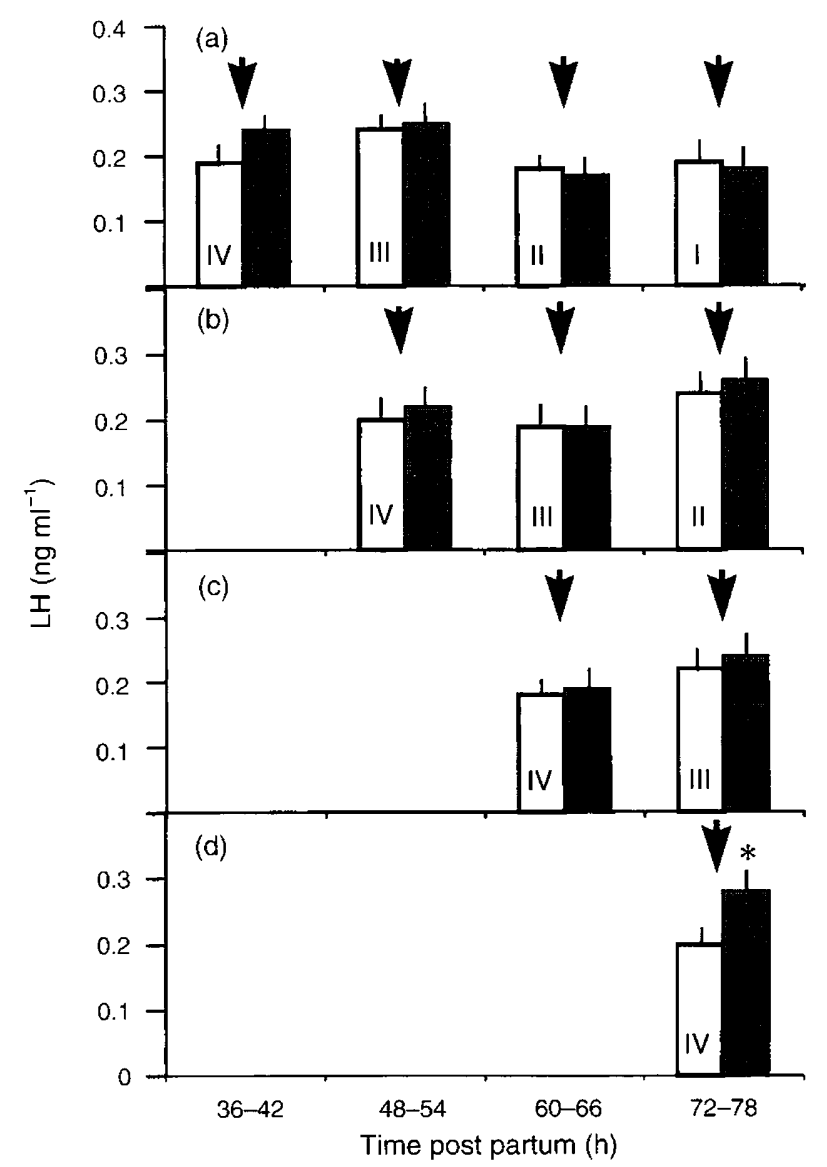

Fig. 3. Mean (+SEM) plasma LH concentrations during control pretreatment periods, and after the (a) first (all groups; $n=20$ ), (b) second (groups II, III, IV; $n=15$ ), (c) third (groups III, IV; $n=10$ ) or (d) fourth (group IV; $n=5$ ) injection of $2 \mathrm{mg}$ naloxone $\mathrm{kg}^{-1}$ between 36 and $78 \mathrm{~h}$ post partum. Arrows indicate naloxone injections. ${ }^{*}$ Indicates a significant effect of naloxone $(P<0.05)$.

\section{Plasma prolactin}

Experiment 1. Neither single injections of $2 \mathrm{mg}$ naloxone $\mathrm{kg}^{-1}$ for the first time at 39,51, 63 and $75 \mathrm{~h}$ post partum nor repeated injections of $2 \mathrm{mg}$ naloxone $\mathrm{kg}^{-1}$ at $12 \mathrm{~h}$ intervals affected mean plasma prolactin concentrations $(P>0.05$; Fig. 5).

Experiment 2. The first $2 \mathrm{mg}$ naloxone $\mathrm{kg}^{-1}$ injections on day 10 and day 11 , respectively, in MI and SI group sows decreased $(P<0.05)$ mean prolactin concentrations. Multiple naloxone injections during day 10-11 of lactation consistently suppressed mean plasma prolactin $(P<0.05)$ (Fig. 6). Furthermore, the response to the $2 \mathrm{mg}$ naloxone $\mathrm{kg}^{-1}$ injections on day 11 in the MI group was not different $(P>0.05)$ from the first injection of $2 \mathrm{mg}$ naloxone $\mathrm{kg}^{-1}$ on day 10 in the same sows.

\section{Discussion}

Active LH secretion in the immediate postpartum period followed by a gradual suppression of LH some $48-55 \mathrm{~h}$ post partum has been described by De Rensis et al. (1993a, b) and 


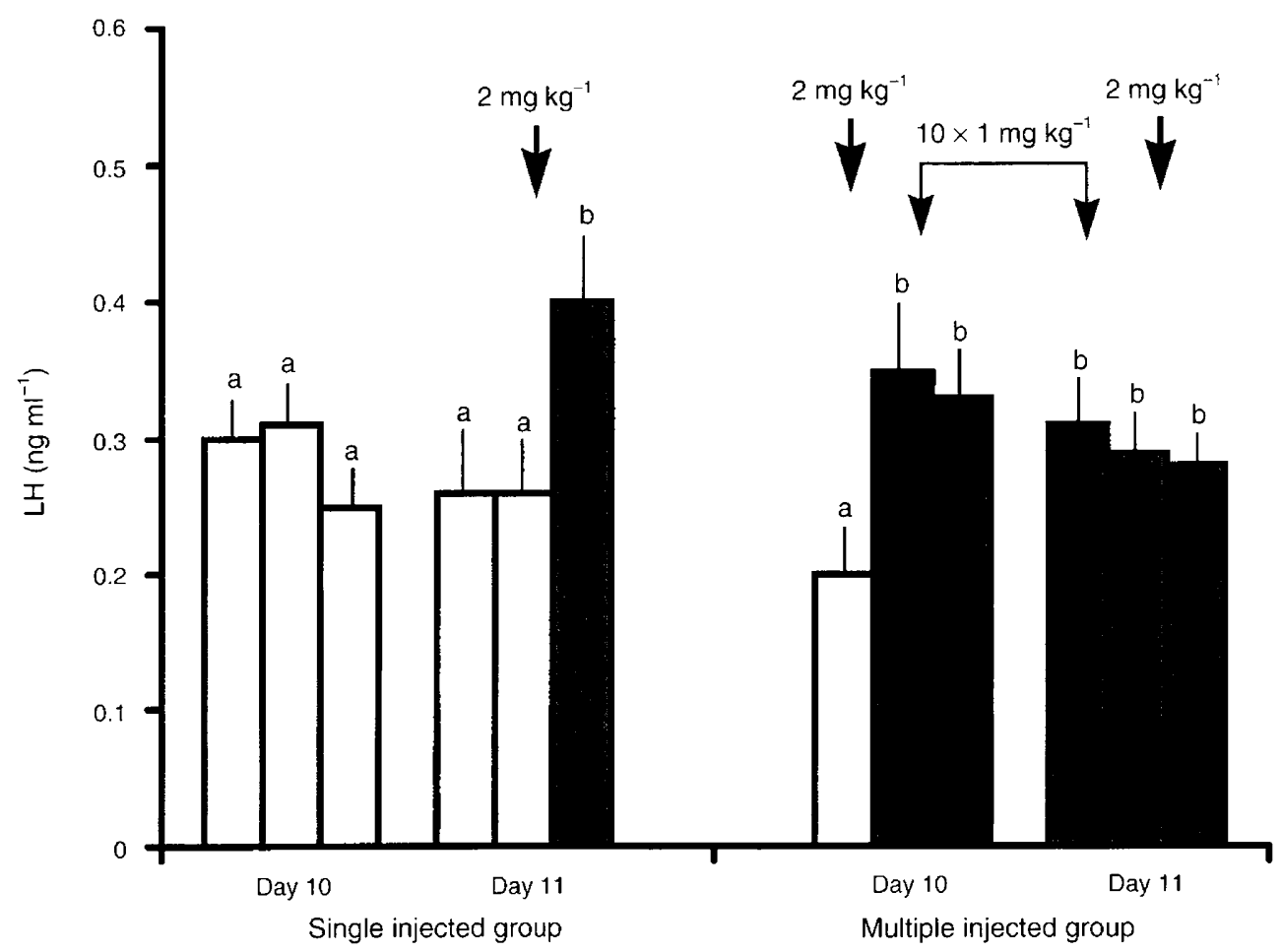

Fig. 4. Mean ( + SEM) plasma LH concentrations in single naloxone injected and multiple naloxone injected sows for three periods of blood sampling on day 10 ( $3 \mathrm{~h}, 3 \mathrm{~h}$ and $3 \mathrm{~h}$ ) and day 11 ( $1 \mathrm{~h}, 3 \mathrm{~h}$ and $3 \mathrm{~h}$ ) of lactation. Arrows indicate naloxone injections. ${ }^{\text {ab }}$ Values with different superscripts are significantly different $(P<0.05)$ between period means within groups.

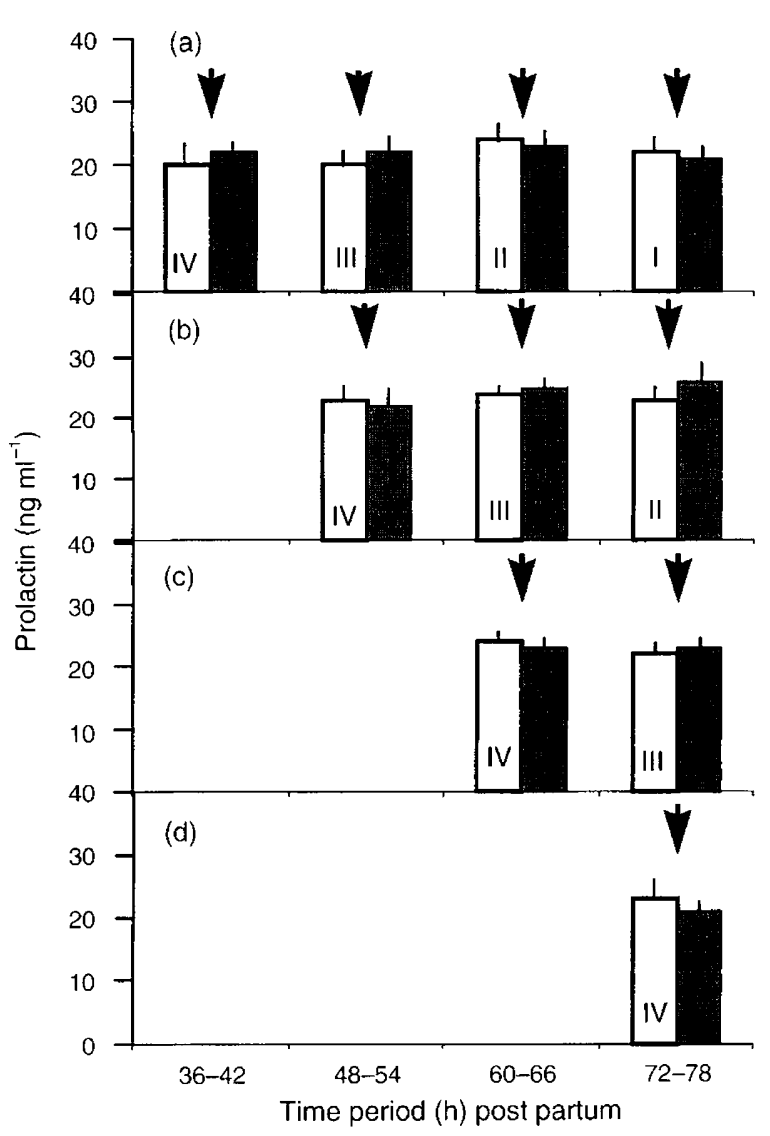

Sesti and Britt (1994). However, in the present study, LH secretion was already inhibited at the start of sampling $36 \mathrm{~h}$ after farrowing, indicating that effective suckling-induced inhibition of LH secretion was already in place. Therefore, by administering the opioid antagonist naloxone, this experimental paradigm was used to confirm our previous hypothesis that opioids are not involved in this initial inhibitory mechanism (De Rensis et al., 1993a). In addition, it was possible to determine the time at which treatment with naloxone first affected $\mathrm{LH}$ and prolactin secretion and, thus, to define precisely the ontogeny of this opioid-dependent inhibitory mechanism.

During the early postpartum period, single injections of $2 \mathrm{mg}$ naloxone $\mathrm{kg}^{-1}$ increased plasma LH only in group IV sows treated for the fourth time $75 \mathrm{~h}$ post partum. In contrast, LH secretion was consistently increased after naloxone treatment on day 10 and 11 of lactation. These data confirm the previous report (De Rensis et al., 1993a) that endogenous opioids do not appear to mediate the initial inhibitory effects of suckling on LH secretion in the early postpartum period, but that inhibitory opioidergic regulation of LH secretion becomes active after this time. Furthermore, since opioidergic regulation

Fig. 5. Mean ( + SEM) plasma prolactin concentrations during control pretreatment periods, and after the (a) first (all groups; $n=20$ ), (b) second (groups II, III, IV; $n=15$ ), (c) third (groups III, IV; $n=10$ ) or (d) fourth (group IV; $n=5$ ) injection of $2 \mathrm{mg}$ naloxone $\mathrm{kg}^{-1}$ between 36 and $78 \mathrm{~h}$ post partum. Arrows indicate naloxone injections. 


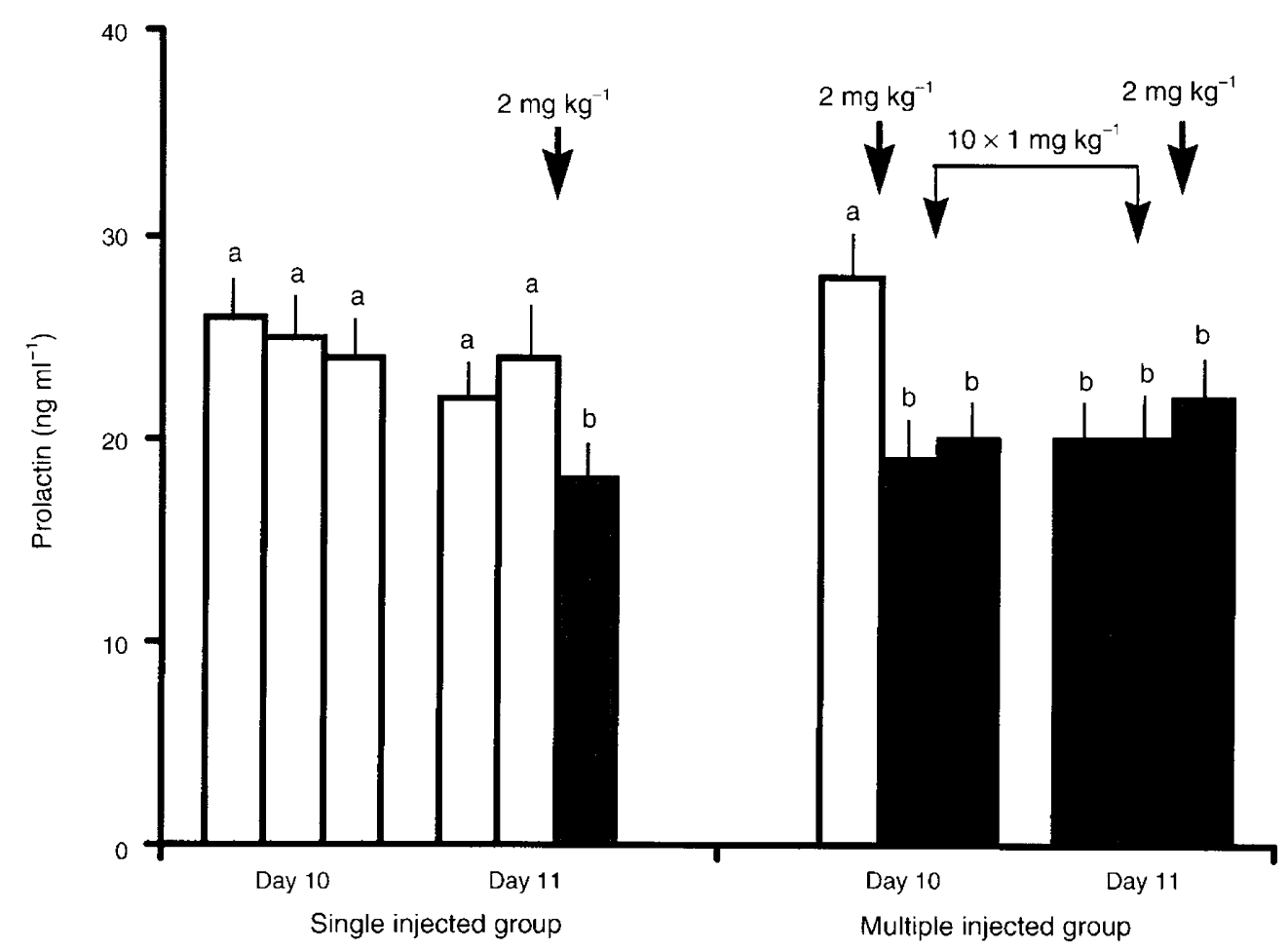

Fig. 6. Mean ( + SE:M) plasma prolactin concentrations in single naloxone injected and multiple naloxone injected sows for three periods of blood sampling on day $10(3 \mathrm{~h}, 3 \mathrm{~h}$ and $3 \mathrm{~h}$ ) and day 11 ( $1 \mathrm{~h}, 3 \mathrm{~h}$ and $3 \mathrm{~h}$ ) of lactation. Arrows indicate naloxone injections. ${ }^{a b}$ Values with different superscripts are significantly different $(P<0.05)$ between period means within groups.

of $\mathrm{LH}$ and prolactin secretion occurs as late as day 108 of pregnancy in the sow (Willis et al., 1996), the absence of opioidergic regulation immediately after parturition seems to be a relatively transient phenomenon. Evidence for differential opioidergic control of $\mathrm{LH}$ secretion in the early and later postpartum periods has also been reported from studies in lactating rats (Wu et al., 1992), although comparable studies in other domestic species are lacking. Therefore, inhibition of $\mathrm{LH}$ release in the early postpartum period in sows may be mediated by a non-opioidergic mechanism. It is still possible that $\mathrm{LH}$ release in the early postpartum period is subject to opioidergic inhibition that is not antagonized by the dose of naloxone used in this experiment. However, higher doses of naloxone produce noticeable side effects and the dose used in the present study is believed to be in the upper physiological range. Another possibility is that opioidergic effects are mediated by opioid receptors not readily antagonized by naloxone; however, naloxone binds to $\mu, \delta$ and $\kappa$ receptors in brain tissue (Chang et al., 1984) and it has been reported that opioids implicated in suppression of $\mathrm{LH}$ are of the $\mu$ type (Pfeiffer et al., 1983). Assuming that the use of naloxone was appropriate, the lack of a response to opioid antagonism in the early postpartum period may be explained in two ways. Either endogenous opioid peptide secretion is absent and, therefore, cannot be antagonized, or a lack of opiate receptors prevents both the opioids or opioid antagonists from exhibiting their effects. To address these possibilities, treatment with the opioid agonist morphine has been used in a companion study (F. De Rensis, J. R. Cosgrove, H. J. Willis, S. Hofacker and G. R. Foxcroft, unpublished).
The concern addressed in Expt 2 of the present study, that the multiple naloxone injection regimen used in earlier work (De Rensis et al., 1993a) may have confused the interpretation of the data, is found in data from other species. In rats (Owens and Cicero, 1981) and rams (Ebling and Lincoln, 1985), repeated naloxone administration is associated with a decline in the LH response to antagonist treatment. Similarly, Knight et al. (1986) did not obtain a significant naloxoneinduced increase of serum LH in suckled ewes when naloxone was administered in small doses (4.17 mg per ewe) every $5 \mathrm{~min}$ for $75 \mathrm{~min}$. Conversely, Myers et al. (1989) in beef cows and Rawlings et al. (1991) in rams, did not observe any diminution of the effect on LH secretion in response to repeated naloxone injections at $2 \mathrm{~h}$ intervals. In the present study, when naloxone was injected every $3 \mathrm{~h}$ during day 10-11 of lactation, mean LH concentrations were consistently increased throughout the period of treatment. Furthermore, the repeated injection of naloxone over this $72 \mathrm{~h}$ did not result in any decrease in the response to a standard challenge with $2 \mathrm{mg}$ naloxone $\mathrm{kg}^{-1}$. Therefore, the lack of a response to repeated naloxone treatment in the immediate postpartum period in the previous study (De Rensis et al., 1993a) was unlikely to have been a result of the multiple injection schedule adopted.

As in previous studies (Barb et al., 1986; Armstrong et al, 1989; De Rensis et al., 1993a), three sows of the SI group and two sows of the MI group did not respond to naloxone treatment on day 10 or day 11 of lactation. The cause of this lack of responsiveness in individual animals continues to be unknown. 
The decline in prolactin secretion after naloxone treatment on days 10-11 of lactation was consistent with data from previous studies in lactating sows, which established an effect of naloxone injection on plasma prolactin in sows treated on day 10 or 11 (De Rensis et al., 1993a), day 15 (Mattioli et al., 1986), day 21 (Armstrong et al., 1989) and day 22 (Barb et al., 1986) post partum. However, naloxone treatment did not change plasma prolactin during the first $78 \mathrm{~h}$ after farrowing, confirming the previous suggestion (De Rensis et al., 1993a) that a non-opioidergic mechanism is involved in the regulation of prolactin secretion during the early postpartum period in suckled sows.

The ability of naloxone treatment to affect $\mathrm{LH}$ and prolactin secretion on days 10-11 of lactation in sows, together with the lack of an effect of naloxone during the first $78 \mathrm{~h}$ post partum, indicates that non-opioidergic mechanisms can mediate the inhibitory effect of suckling on LH and prolactin secretion in the immediate postpartum period. Parallel studies are designed to determine whether functional opioidergic receptors are present in the immediate postpartum period, when naloxone is unable to affect LH and prolactin secretion (De F. Rensis, J. R. Cosgrove and G. R. Foxcroft, unpublished). However, the present data confirm that, in late lactation, the opioidergic system is effective in regulating $\mathrm{LH}$ and prolactin secretion, and this opioidergic mechanism does not become refractory to repeated challenges with the opioid antagonist naloxone.

This study was supported by grants from NSERC and the Alberta Pork Producers Development Corporation (Canada), contribution 95.04411.CT04 from the Consiglio Nazionale delle Ricerche (Italy), and contributions to the provision of experimental animals by Pig Improvement (Canada) Ltd. The authors also acknowledge the generous provision of assay reagents by E. H. F. Erkens and K. Kochmann.

\section{References}

Armstrong JD, Kraeling RR and Britt JH (1989) Effects of naloxone or transient weaning on secretion of $\mathrm{LH}$ and prolactin in lactating sows Journal of Reproduction and Fertility 83 301-308

Barb CR, Kraeling RR, Rampacek GB and Whisnant CS (1986) Opioid inhibition of luteinizing hormone secretion in the postpartum lactating sow Biology of Reproduction 35 368-371

Barb CR, Kraeling RR and Rampacek GB (1991) Opioid modulation of gonadotropin and prolactin secretion in domestic farm animals Domestic Animal Endocrinology 91 15-27

Britt JH, Armstrong JD, Cox NM and Esbenshade K (1985) Control of follicular development during and after lactation in the sow Journal of Reproduction and Fertility Supplement 33 37-54

Britt JH, Armstrong JD, Moore KL and Sesti LAC (1992) Involvement of opioids in regulation of $\mathrm{LH}$ secretion during lactational- or nutritional-induced anoestrus in pigs and cattle. In Opioids in Farm Animals pp 34-54 Ed. N Parvizi. Landwirtschaftsverlag $\mathrm{GmBH}$, Hannover

Chang KJ (1984) Opioid receptors: multiplicity of ligand-receptor interactions. In The Receptors Vol. 1 pp 1-81 Ed. PM Conn. Academic Press, New York Cosgrove JR, Urbanski HF and Foxcroft GR (1993) Maturational changes in gonadotrophin secretion: the LH response to realimentation and a nocturnal increment in LH secretion of feed-restricted prepubertal gilts Journal of Reproduction and Fertility 98 293-300
De Rensis F and Foxcroft GR (1992) Endogenous opioid modulation of gonadotropin and prolactin secretion in the postpartum sow. In Opioids in Farm Animals pp 15-33 Ed. N Parvizi. Landwirtschaftsverlag GmBH, Hannover

De Rensis F, Cosgrove JR and Foxcroft GR (1993a) LH and prolactin responses to naloxone vary with stage of lactation in the sow Biology of Reproduction 48 970-976

De Rensis F, Hunter MG and Foxcroft GR (1993b) Suckling-induced inhibition of LH secretion and follicular development in the early postpartum sow Biology of Reproduction 48 964-969

Ebling FJP and Lincoln GA (1985) Endogenous opioids and the control of seasonal LH secretion in Soay rams Journal of Endocrinology 10 341-353

Foxcroft GR (1992) Nutritional and lactational regulation of fertility in sows Journal of Reproduction and Fertility Supplement 45 113-125

Foxcroft GR, Haresign NB, Haynes NB, Lamming GE and Peters AR (1988) Gonadotrophins: domestic animals Acta Endocrinologica 288 41-50

Gregg DW, Moss GE, Hudgens RE and Malven PV (1986) Endogenous opioid modulation of luteinizing hormone and prolactin in postpartum ewes and cows Journal of Animal Science 63 838-847

Haynes NB, Lamming GE, Yang KP, Brooks AN and Finnie AD (1989) Endogenous opioid peptides and farm animal reproduction. In Oxford Reviews of Reproductive Biology Vol. II pp I5-33 Ed. SR Milligan. Oxford University Press, Oxford

Knight PG, Howles CM and Cunningham FJ (1986) Evidence that opioid peptides and dopamine participate in the suckling-induced release of prolactin in the ewe Neuroendocrinology 44 29-35

Mattioli M, Conte F, Seren E and Galeati G (1986) Effect of naloxone on plasma concentrations of prolactin and LH in lactating sows Journal of Reproduction and Fertility 76 167-173

Myers TR, Myers DA, Gregg DW and Moss GE (1989) Endogenous opioid release of luteinizing hormone during suckling in postpartum anestrous beef cows Domestic Animal Endocrinology 6 183-190

Owens DP and Cicero TJ (1981) Development of acute tolerance to the effects of naloxone on the hypothalamic-pituitary-luteinizing hormone axis in the male rat Journal of Pharmacology and Experimental Therapy 216 135-141

Pfieffer DG, Pfeiffer A, Shimohigashi Y, Merriam GR and Loiaux DL (1983) Predominant involvement of mu-rather than delta or kappa-opiate receptors in LH secretion Peptides 4 647-649

Rawlings NC, Churchill IJ, Currie WD and Joseph IB (1991) Maturational changes in opioidergic control of luteinizing hormone and follicle stimulating hormone in ram lambs Journal of Reproduction and Fertility 93 1-7

Rockville MD (1996) The United States Pharmacopeian Convention Rockville, MD 2127-2128

SAS (1985) SAS User's Guide: Statistics Statistical Analysis System Institute Inc. Cary, NC

Sesti LAC and Britt JH (1994) Secretion of gonadotropins and estimated releasable pools of gonadotropin-releasing hormone and gonadotropins during establishment of suckling-induced inhibition of gonadotropin secretion in the sow Biology of Reproduction 50 1078-1086

Shaw HJ and Foxcroft GR (1985) Relationship between LH, FSH, and prolactin secretion and reproductive activity in the weaned sow Journal of Reproduction and Fertility 75 17-28

Smith CA, Almond GW and Dial GD (1992) Changes in luteinizing hormone concentrations after abortion, parturition and weaning in primiparous sows Animal Reproduction Science 27 169-182

Steel RGD and Torrie JH (1980) Principles and Procedures of Statistics 2nd edn. McGraw-Hill Book Company, New York

Varley MA and Foxcroft GR (1990) Endocrinology of lactation Journal of Reproduction and Fertility Supplement 40 47-61

Willis HJ, Cosgrove JR and Foxcroft GR (1996) Opioidergic control of luteinizing hormone and prolactin secretion in late gestation in the sow Biology of Reproduction 55 318-324

Wu T, Mc Hartur NH and Harms PG (1992) possible dual mechanism involved in the inhibitory influence of suckling on luteinizing hormone release in the ovariectomized rat Biology of Reproduction 46 653-657 